This is a peer-reviewed, accepted author manuscript of the following article: Lewin, D. (2020). Between horror and boredom: fairy tales and moral education. Ethics and Education.

https://doi.org/10.1080/17449642.2020.1731107

\title{
Between Horror and Boredom: Fairy Tales and Moral Education ${ }^{1}$
}

\author{
David Lewin, University of Strathclyde
}

Where do a child's morals come from? Beyond the question of the extent to which morality is given by nature, the range of influences on the morality of the child are diverse. Interactions with other human beings provide arguably the primary contexts for moral development: family, friends, teachers and other people. It is the artistic products of human activity that this essay considers: literature, film, art, music. More specifically, I will consider some philosophical issues concerning the influence of folk and fairy tales on moral development. I will discuss issues of representation and reduction: in particular, how far should stories for children elide the complexities inherent to many folk and fairy tales? Drawing on a distinction between a problematic reductionism and an appropriate pedagogical reduction, I suggest that pedagogical issues of representation require us to think about how to represent complexity in ways that are reductive without being reductionist, that can delight and engage without being horrifying or tedious. While there is a place for horror and for boredom, it is primarily a matter of timing...

\section{Once upon a time...}

Once upon a time we heard tales of strange beings and curious events. We listened intently as stories unfolded a world of enchanted forests, curious animals, wicked stepmothers, handsome princes and princesses in waiting. Despite (or perhaps because of) the fact that folk and fairy tales have often presented prejudicial and archaic stereotypes such as these (Haase 2004), their appeal endures. From Aesop's Fox and Crow to Julia Donaldson's Gruffalo, ${ }^{2}$ from Grimm's Little Red Riding Hood to Disney's Frozen, folk and fairy tales appear to be a general feature of human culture, ${ }^{3}$ and show no sign of going out of fashion.

There have been many efforts to define and organise folklore and fairy tales, such as the AarneThompson-Uther Index of folktales ${ }^{4}$ and the Amalia Märchenlexikon. ${ }^{5}$ These indices include such a wide variety of stories that it is apparent that the purposes and intended readership of these stories are diverse. Firstly, many of these stories are not directed to children (Zipes 2007, 1). Even if we (anachronistically) supposed that something like 'children's literature' existed when these various tales originated (which is highly unlikely, see Grenby 2014), the argument that they were intended to influence the moral formation of children would, in many cases, be hard to prove. Yet there is a subset

\footnotetext{
${ }^{1}$ I would like to express my gratitude to colleagues, particularly Paul Adams and Karsten Kenklies, who have commented on drafts of this paper. May I also express thanks to Morten Korsgaard and Johan Dalhbeck for encouraging and supporting publication.

${ }^{2}$ Is Gruffalo a fairy tale?: "Part of The Gruffalo's appeal is that it is a proper fairy tale, and doesn't rely on the reflexive "prosocial" correctness that can afflict children's literature. 'It avoids the finger-wagging stuff to which some succumb, myself included,' Michael Rosen once said. 'There is a wider moral, in that the small person can outwit the big person. But while it has a moral, it isn't moralising.'” (Rasmussen 2019).

${ }^{3}$ This selection is likely to be well known among readers from the UK. For a much broader perspective on folk and fairy tale themes that exist around the world see, for instance, Yolen (2014).

${ }^{4}$ The index was first developed by Aarne in 1910 (Aarne 1961) for European tales and later expanded by Thompson (1955) to include more diverse tales from Europe as well as India.

${ }^{5}$ See http://www.maerchenlexikon.de/inhalt.htm. See also Charles Perrault's tales (Carter 2008) and the Grimm Brothers' Children's and Household Tales (1812-57), two key collections in the history of Western fairy tales.
} 
of stories and tales in which educational intentions can reasonably be attributed, for instance Newbery's 1744 publication, A Little Pretty Pocket Book (Newbery 1770). From around the mid-eighteenth century, the notion of children's literature emerges, and so we can more plausibly imagine that folk stories have some didactic intent: e.g. warning of the dangers of wandering off into the forest; that lying is wrong; that justice prevails... they all live happily ever after. Apart from explicitly didactic literature, the educational intentions of the author are notoriously slippery since many stories have roots in traditional folk tales whose origins lie in oral traditions, making the quest for an original meaning tricky if not entirely hopeless. ${ }^{6}$

Putting the undecidable issue of authorial intention to one side, we can more reliably examine how these stories are read and used. Often folk and fairy tales are used by parents and educators for all sorts of reasons from soothing and stimulating young children (Danilewitz 1991), to learning to read (Winch et al. 2014), to critical literacy (Bourke 2008). It seems then, that even though the characters and events may be quite strange and fabulous, often drawing on dark, magical and mysterious themes, they frequently (with some notable exceptions) make enough sense for lessons to be drawn. In view of the complexity and the range of stories, it is not surprising that editors have chosen to select certain tales (Carter 2008), and then to reinterpret them so that certain problematic elements or 'adult themes' are removed, or so that the moral of the story can be explicit. ${ }^{7}$ Not only do parents and teachers use them to engage young people in various forms of literacy, they are also thought to open up spaces for discussion of difficult issues such as betrayal, death, greed, and vanity. These difficult issues are not presented systematically as philosophical problems or as empirical questions, but are brought to life through narrative and symbol. Narrative and symbol seem to offer indirect means of communication, and might therefore, be regarded as not the most effective means to communicate a simple message with clarity, again suggesting that these kinds of stories are not didactic: intended for direct moral instruction. The widespread use of these tales in educational contexts may be better explained by the idea that they are often intended to raise issues that are not easily discussed or explained in explicit or direct ways. In his book Incest in Indo-European Folktales the American folklorist, D.L. Ashliman makes precisely this point, "many fairy tales owe their longevity to an ability to address tabooed subjects in a symbolic manner" (Ashliman, 1997). It is plausible that the indirect nature of story and symbol can form more appropriate pedagogical spaces in which to explore complex ethical and existential ideas. It may depend, in part, on what is meant by 'direct' and 'indirect' a point to be discussed later on. If it is true that narrative and symbol offer imaginative contexts in which to explore ethical problems, then it might explain the widespread use of similar symbolic discourses in the myths and narratives of religious traditions the world over, a point I cannot discuss in this paper. First let me outline my argument in more detail.

As part of a Special Issue on the concept of exemplarism, this paper broadly addresses ideas of how particular moral notions and principles are exemplified in narrative forms specifically that of folk and fairy tales. Thus, there are strong affinities with wider considerations of exemplarism in reference to the representation of ideas, values and principles. My argument builds on the idea that education involves the intentional representation of some aspect of the world, a kind of pedagogical 'virtual reality'. I call

\footnotetext{
${ }^{6}$ The 'The Death of the Author' Barthes (1977) argues against the approach of literary criticism which attempts to interpret the text through understanding authorial intention. In the context of pedagogy, although intention is very significant since it allows for some kind of systematic distinction between all kinds of diverse socialising influences and those that have an educational aim, the intentions are less of the author than of the educator who employs the text for some pedagogical purpose.

${ }^{7}$ For a good example of a modern selection with moral education in mind, see Bennett (1994).
} 
this virtual not because it is technological or computer generated, but because it is an imaginal space for pedagogical exploration, or to use a phrase from Klaus Mollenhauer, a space for 'pedagogical rehearsal' (Mollenhauer 2013). Within this imaginal space, the narrative structures of folk and fairy stories are not simply arbitrary vessels in which moral lessons are carried. It would be excessively reductive to view these stories as only concerned with the transmission of otherwise all too dry and uninspiring practical or moral lessons, as no more than literary exemplifications of certain principles. In contrast to this, I take the view that the narrative forms and symbols within the stories are significant in their own right: the fact that they exist, and are deployed in (and as) a 'virtual reality' does not, in this sense, make them inauthentic or dispensable, or even diminish them in terms of their intended use.

However, whereas spaces for pedagogical rehearsal are typically simplifications of complex phenomena, what I have elsewhere called 'pedagogical reductions' (Lewin 2019), the stories of folk and fairy tales are often thought to be intrinsically complex and ambivalent, resistant to tendencies to reduce them to simple moral lessons. It is the juxtaposition of pedagogical intentions in employing folk and fairy tales, and the apparent irreducibility of them that provides the dynamics on the argument. So, despite the (qualified) irreducibility of certain tales and their telling, moral lessons can be distilled. But drawing moral lessons from these stories ought to entail a self-conscious, and therefore intentional simplification and reduction, a reduction in which we carefully consider what interpretations are significant for us and why. Moreover, that reduction always recognises that there are other ways of reading the text, that there is always more that could be said, though for pedagogical purposes certain restrictions are put in place.

In general, the concept of pedagogical reduction refers to the intentional selections, simplifications and representations of aspects of the world for pedagogical purposes. To give a preliminary example of this pedagogical reduction in the sphere of moral education through folk and fairy tales, consider the following question: if we want to teach young children that lying is wrong, what should we use? We might be better off using Pinocchio than Kant since it seems to offer a more engaging opportunity to consider the morality of truth and falsehood. It is not easy to say what precisely makes Pinocchio more engaging, though it is plausible that the dynamics of action and consequence in relation to truth and falsehood are illustrated in more entertaining ways in the various interpretations of Pinocchio and that, therefore, the story lends itself better to didactics, and also to pedagogical reduction. However, we should ask ourselves what are the losses as well as the gains in this kind of reduction, and what pedagogical and didactic circumstances influence the choice of pedagogical reduction (for instance, the age and context of the child), and indeed, whether Pinocchio really is straightforwardly didactic. ${ }^{8}$ More generally, there is no shortage of books which promise to organise the wisdom of fables into practical moral lessons for children, such as William Bennett's The Book of Virtues: A Treasury of Great Moral Stories, (with spin-off $\mathrm{TV}$ shows ${ }^{9}$ ). These stories are told and retold, often with the moral lesson being explicitly pressed home. For some this risks artlessly reducing the experience of literature to the transmission of a dead message, to moralising. In 1808 Samuel Taylor Coleridge argued against the

\footnotetext{
${ }^{8}$ Wunderlich and Morrissey claim that "Despite repeated efforts to reduce Pinocchio to a didactic text with fixed meaning, there is much in the book that smacks of indeterminacy, a hallmark of postmodern fiction" (Wunderlich and Morrissey 2002, 169). Moreover, if we do use Pinocchio it is not because of a commitment to the original story as told by the Italian writer Carlo Collodi in 1883. Intended as a tragedy and a warning, the original tale presents Pinocchio as a rascal and a confirmed rogue who meets his end when his enemies, the Fox and the Cat, bind his arms, tie a noose around his throat, and hang him from the branch of an oak tree.

${ }^{9}$ Adventures from the Book of Virtues is an American animated television series based on Bennett's The Book of Virtues: A Treasury of Great Moral Stories.
} 
moralising of fairy tales, saying that these stories "do not teach goodness - but if I might venture such a word - goodyness" (Morley 1922, 107). Even earlier in 1762, Jean-Jacques Rousseau argued that the moral lessons of Aesop's fables are unclear, not least because of the unnatural characterisations and contexts that the stories present. This seems to broadly resonate with the complaints against the overly didactic use of stories (Repp 2012). In English 'didactics' often refers to a directive form of moral instruction which expresses moral imperatives in a straightforward manner: “'Don't hit your brother', 'Don't lie to me' and 'Don't take things that aren't yours'” (Hand 2017, 47).$^{10}$ If stories are thought to be overly didactic it suggests a concern about the pedagogical approach or methods being employed. This article addresses the usage of representations and employs the designation pedagogical representation as a descriptive term: describing the process of employing representations for educational/pedagogical purposes, henceforth avoiding the term 'didactic' because of the critical note sometimes heard in it, at least in its use in contemporary English. The focus here is primarily on the way the stories are used, what I will later describe as the give and take of pedagogical representations which, I suggest, is vital to the art of educating. Whether folk and fairy tales are themselves simple, and many appear not to be, they have been used to engage children and young people in understanding and reflecting upon more or less complex aspects of the world. I will take my first main point of reference to be the dawning of the progressive education tradition by looking at the different views of these matters taken by John Locke and Jean-Jacques Rousseau.

\section{Enlightenment and Enchantment}

For Locke fables and fairy tales were literary devices whose primary purpose was to help children learn to read rather than to encourage the imaginative or poetic faculty. Indeed, Locke claimed that if a child "had a poetic vein...the parents should labour to have it stifled and suppressed as much as may be" (Locke 2000, 80). For Locke, the pedagogical significance of Aesop's Fables was less to do with their direct capacity for moral development, than the fact that they are "apt to delight and entertain a child" (Locke 2000, 70) and thus offer appropriate texts to engage children towards the complex task of learning to read. The moral lessons of fables are likely only to be appreciated later where they might provide "useful reflections to a grown man" (Locke 2000, 70).

Rousseau's views of the meaning and matter of using fables differ dramatically from Locke's firstly because he was suspicious of children reading, and second because folk tales were particularly confusing for children. Rousseau's general view that childhood is originally a state of peace and innocence (Rousseau 1992) which education, for the most part, threatened to corrode, meant that reading was interpreted as "the plague of childhood" (Rousseau 1979, 116) to be avoided for as long as possible. Furthermore, in Rousseau's view the specific form of the fable presented particular problems for the education of children because fables generally employ unfamiliar concepts, difficult terminology, and introduce confusing details that obscure the 'moral' of the story:

\footnotetext{
${ }^{10}$ In this sense, 'didactic' is contrasted with an indirect form of influence, sometimes referred to as a 'Socratic' method. For instance, asking why a child hits his brother takes a slightly different route to the moral injunction even if the aim is broadly the same as the expression of the direct moral imperative not to do so. However, this is somewhat more complex because sometimes the term didactic refers to this in a descriptive way, and at other times there is an implicit or explicit criticism that the story is didactic (Repp 2012). The reader should keep in mind that because didactics as a process of instruction is generally out of favour, it is sometimes assumed to be a critical term. The German equivalent 'Didaktik' is more neutral and descriptive in this sense.
} 
All children are made to learn the fables of La Fontaine, but there is not one of them who understands them. Even if they were to understand them it would be still worse; for the moral in them is so confused, and so out of proportion to their age, that it would incline them to vice rather than to virtue. (Rousseau 1979, 113).

Only mature readers, like Rousseau himself, would be able to identify and draw out the correct interpretation. In Emile Rousseau recounts seeing a "little girl weeping bitterly" (Rousseau 1979, 116) in response to Aesop's fable of the lean wolf and the fat dog. Although the girl identifies with the dog who pays for being well fed with his freedom (symbolised by the collar), the story erroneously encourages her to desire the freedom of the wolf, and therefore to interpret her inevitable bondage to society negatively. Despite Rousseau's antipathy to early societal influence, he believes that this misinterpretation gives the child a lesson in wolfish license rather than moderation. If only the girl had correctly interpreted the fable, she would not have been left in tears. Although Rousseau is generally sceptical of the educational use of fables and fairy tales, it is his assumption here that there is one correct interpretation that I discuss further.

Whether or not one believes that there is one clear and correct interpretation of any particular story has pedagogical significance. If moral education is understood to be about directing students towards established and uncontested moral principles (e.g. that lying is wrong), then we might well anticipate the story of Pinocchio to contain a directive intention: the story can be used to direct the reader to grasp, and to adhere, to a particular moral truth. Thus, the moral can be interpreted as singular and unambiguous. This kind of directive moral education can be contrasted with 'non-directive' moral education, where the moral principles are not clearly established, or are contested, and where a single interpretation is always understood as insufficient. Here children might be encouraged to consider the ethical issues at stake from different perspectives, without a single orthodox or correct interpretation being offered. In general, the more established and stable the ethical issues are, the more justification there may be for directive moral education.

It seems as if moral realism itself might be at stake and that non-directive moral education sits on the fence by failing to offer theoretical or even practical moral guidance. Sommers (2002) argues that where educators avoid directive moral guidance, they do so out of a failure to stand for a moral position, thereby perpetuating moral relativism. But as David Aldridge (2014) has shown, this interpretation is inadequate because it creates too simplistic an opposition between realism and relativism by having a narrow notion of directive education. It is likely that many educators, from parents to schoolteachers, do take a view on what values they hold dear and also wish to encourage their students to take up similar values. Indeed, education is barely conceivable without a normative orientation. ${ }^{11}$ Despite this desire to encourage students towards certain values, educators often realise that the most effective means of such influence might not be through 'direct' means, but often requires indirect means. Direct instruction on moral matters may be ineffective means, but there are many alternatives. For instance, teachers often create spaces for social interaction (e.g. playgrounds) where children engage in forms of social life, which inevitably bring up ethical dilemmas, and where the art of teaching may lie with the teacher asking conflicted students certain questions designed to elicit

\footnotetext{
${ }^{11}$ The fundamentally normative orientation intrinsic to any concept of education has been famously developed in Peters' Ethics and Education (Peters 1966).
} 
reflection and moral reasoning (a broadly Socratic process ${ }^{12}$ ). The goal of such a process is not morally neutral but employs indirect pedagogies with the intention to gently guide. In short, there are more or less directive means by which to realise normative ends. ${ }^{13}$

With reference to the lack of directive moral education, Sommers (2002) also expresses anxiety that our lack of moral commitment reflects a wider moral vacuum within our culture, related to the broader progressive trends in education which appear to avoid explicit moral guidance. Aldridge (2014) has pointed out that Sommers' anxieties are partly a product of her failure to properly distinguish between non-directive pedagogy as a means to achieve normative influence, from a much less credible anxiety that educators are shying away from all forms of normative influence. (It could be argued that this confusion extends to the general polarisation between traditional and progressive education). Yet Sommers' concerns are widely reflected: in the rise of character education in the US (U.S. Department of Education 2005), the UK (see The Jubilee Centre for Character and Virtues 2019), in China (e.g. The Nanjing Institute of Moral Education 2019) and around the world. It is not uncommon for fables and fairy tales to be regarded as a resource that we can turn to in these difficult times and that we should mine the "rich quarry of moral literacy" (Bennett 1994, 12) to be found in this literature.

Regarding fables and fairy tales as a rich quarry that can be mined for moral literacy raises some issues. What are the losses and gains in mining these stories, or distilling their moral essence? Are we indeed uncovering anything, or are we simply obscuring their richness or flattening the literary terrain? In what follows I develop a theory of 'moral reduction' which I believe avoids the pitfalls of reductionism, while acknowledging the proper scope of pedagogical reduction. Before explaining the concept of moral reduction in detail, let me first illustrate the general structure of representation by reference to Aesop's fable, the Fox and the Crow.

\section{The Fox and Crow}

In terms of my discussion of pedagogical representation, Aesop's influential fable of the Fox and Crow has a number of relevant features: it is short; it has been translated into almost every language; it exists in many different forms including verse, paintings and music as well as having been represented on postage stamps and coins; most pertinently, it has received considerable attention as a pedagogic device (Aldridge 2014; Ferguson 1984; Lewis 2012; Shell 1974). Here is the classic telling of the fable:

A crow was sitting on a branch of a tree with a piece of cheese in her beak when a fox observed her and set his wits to work to discover some way of getting the cheese. Coming and standing under the tree he looked up and said, "What a noble bird I see above me! Her beauty is without equal, the hue of her plumage exquisite. If only her voice is as sweet as her looks are fair, she ought without doubt to be queen of the birds." The crow was hugely flattered by this, and just to show the fox that she could sing she gave a loud caw. Down came the cheese, of course, and the fox, snatching it up, said, "You have a voice, madam, I see. What you want is wits" (Aesop 1912, 6).

\footnotetext{
${ }^{12}$ As mentioned earlier, the English the term 'didactic' is often used to name a pedagogically direct method of education (see Hand 2017, Chapter 3). This didactic approach is sometimes loosely contrasted with a Socratic approach which entails the indirect means of asking questions.

${ }^{13}$ For an account of directive and non-directive forms of moral education see Hand (2017).
} 
In the 1690's, the French poet and storyteller Jean de la Fontaine rendered this tale (along with many others) into poetic verse which subsequently lent this, and other fables, to musical rendition. The mnemonic device of verse is, of course, educationally significant because rhymes have long been used to aid memory and to support literacy (Geller 1983). Beyond that change, the story is significantly elaborated as shown in the additional closing lines of the English translation of La Fontaine:



From Aesop to La Fontaine, a certain messaging seems to come to the fore with the added reflection of the crow. The extent to which a moral is highlighted is, at least partly, a matter of pedagogical judgement. In the Internet Age, accessibility is enhanced in different ways (see Figure 1). Although the image here is not so different to what one might find in a modern printed version of the fable, note the arrangement of the text. The text is arranged so that each line is easy to follow for children learning to read along with a visual summary. Here the moral of the story is highlighted through italicisation and centring, though appears with La Fontaine's addition of the reflection of the crow.

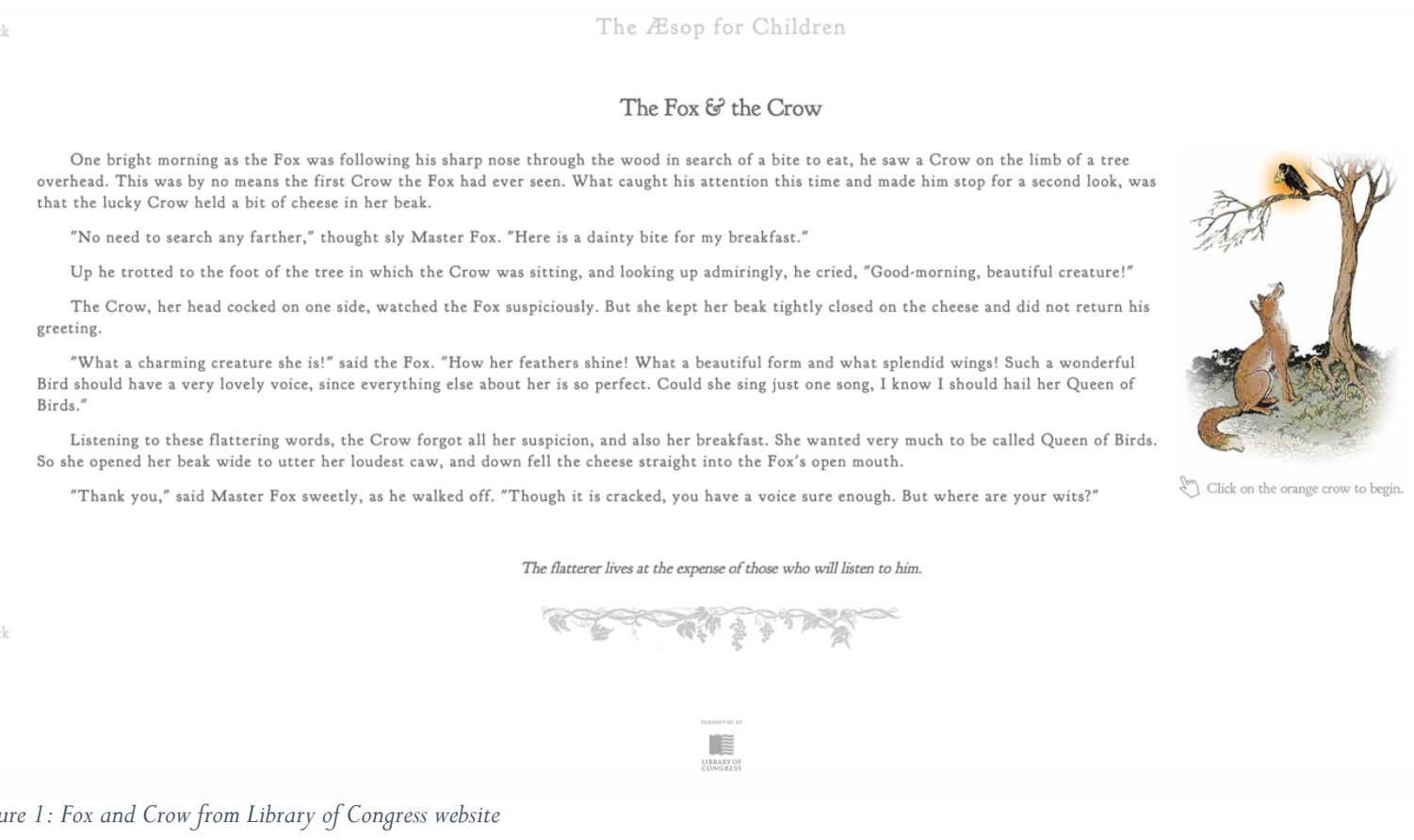

The intention to enhance moral literacy through these pedagogical representations could be considered in light of the complexity of the story itself. It may seem that the story can easily be reduced to a maxim: don't listen to flatterers. But it may not be so simple.

While Rousseau acknowledged that La Fontaine's versification for children could aid memorisation and make the fable more entertaining, he thought this would be at the expense of understanding. As was noted earlier, Rousseau believed that the moral was obscured in these kinds of tale, especially the poetic rendering. Of the Fox and Crow Rousseau worries that the child will naturally identify with the apparent 
winner, the manipulative and crafty fox whose intelligence allows him to exploit the vanity of the crow. Is the ultimate lesson that the powerful or cunning will triumph over the weak or stupid, and is this an important truth for children to learn? The fox announces a lesson to the crow but appears not to demonstrate virtue. Does the character of the fox offer an example of the division of knowledge and virtue that children ought to detect as they navigate social life? As Rousseau suggests, the more general worry might be that younger children are attracted to the cunning that the fox shows in getting his way. David Aldridge neatly captures the contradictions as Rousseau would see them:

If the crow shows us that we ought to learn from our mistakes, then here is a fool who is to be imitated. If the fox can claim to teach the moral message, then here is a teacher who is not be imitated. Why would a tutor choose to educate a young child with this fable, Rousseau asks, when he must then persuade that child to perform such a complicated inversion? (85)

Of course, such tales might not only invite imitation, but might also encourage reflection. But at what stage are children prone to imitate, or to reflect? Without elaborating a theory of moral development, there seem to be different ways of reading this story. My point earlier was that Rousseau seems concerned to conceal the polysemic nature of the text, certainly where the text is thought to be didactic, a concern that is evident in his complaint that the moral of the story should be obvious:

Nothing is so vain or so ill conceived as the moral with which most fables end - as if this moral were not or should not be understood in the fable itself in such a way as to be palpable to the reader. Why, then, by adding this moral at the end, take from him the pleasure of finding it on his own? (Rousseau Emile, 248)

It is true that Rousseau also has in mind the pedagogical method here that natural education entails, as far as possible, a process of autonomous discovery.

The enduring cultural appeal of this tale is further illustrated by its appropriation by Chinese authors. Indeed, Aesop's fables were the first Western literature (apart from religious texts) to be translated into Chinese. The text, published in 1625, entitled Kuan Yi (Moral Tales) comprised 22 of Aesop's fables (Qi 2012, 24). Of course, translation involves interpretation, and in the case of Aesop's fables, the initial translations were quickly reinterpreted and revised. Shouhua Qi observes that Li Shixiong's (1602-1686) revised translation of the story, which appeared only a few years later than the first Chinese translation, was reinterpreted with additional lines at the end:

Upon seeing the fox, the Pheasant denounced him furiously: 'Calling the black white to steal the meat, you thief!' Upon seeing the row, the Peacock said, laughing, 'Not knowing who you are, you eat up the Fox's flattery' (Qi 2012, 26).

Qi point out that these additional lines in Shixiong's translation add an additional interpretive layer through the observations of the Pheasant and the Peacock and provide a more explicit moral lesson. Furthermore, Qi argues that this addition was intended to deliver direct and poignant social commentary by making "thinly disguised jabs at rampant corruption... in the society of his time" (Qi 2012, 26). Qi's more general point is that as these stories are appropriated by Chinese culture, the morals contained therein are made more visible, "both textually and topographically, perhaps to better deliver the instructional (didactic) function of the stories" (Qi 2012, 25). This general tendency for folktales to undergo constant re-interpretation and re-presentation is no doubt related to their origins in oral traditions. But the larger point I wish to make here is the nature of pedagogical representation by way of what I call moralistic reduction. 


\section{The Moralistic Reduction}

In order to clarify the hermeneutical questions of moral education through fables and fairy tales, I propose the term moralistic reduction to define the intentional re-interpretation and re-presentation of a story or text in order to distil a simple (if not singular) moral lesson. Reducing one of Aesop's fables to a maxim is a particular case of this. The moralistic reduction can be seen as a specific form of a more generalised pedagogical reduction, which I have defined elsewhere in terms of the ways in which complex aspects of the world are simplified and represented for pedagogical purposes (Lewin 2019). In discussing the pedagogical reduction, I argued that, although progressive educators might worry about the authenticity of children's learning through pedagogical representations, education cannot take place without some kind of re-presentation and reduction. Similarly, while moralistic reductions elide certain details and exclude the often complex dynamics of a story, they have an important pedagogical role to play in guiding children. We are more likely to appreciate the need for something akin to a pedagogical or moralistic reduction if it is viewed in relation to the fact that childhood is not (only) a biological state, but to a large extent socially/culturally formed. In other words, although young humans have always existed, 'childhood' has not. The formation of childhood, as a distinct phase of life which requires a set of distinct educational resources, activities and representations, only really emerged during the seventeenth century (Aries 1962; Mollenhauer 2013). As the concept of childhood as a formative period developed, so resources for children were increasingly required. Children's literature as a separate genre developed only in the eighteenth century (Nikolajeva 1995). It seems plausible, then, that the ways that stories have been reinterpreted for children is part of a more general construction of childhood. It is, then, understandable to consider the ways that children engage in social and ethical life, and how something akin to a moralistic reduction might have a place.

In Forgotten Connections, Mollenhauer discusses a key aspect of the formation of childhood through the distinction between presentation and re-presentation. Prior to the seventeenth century, children were, in general, simply present to the ('adult') world. Only with the construction of childhood do we find questions of a more systematic nature concerning how and why we ought to re-present aspects of the world in specific educational forms: "the realm of schooling consists of a huge montage of images and representations which are not 'the things themselves' but that instead 'point out' things and phenomena" (2013, 34). For Mollenhauer, the questions of pedagogical representation and the construction of childhood are related. Texts then become transformed from (among other things) general interest and entertainment, to pedagogical devices. Where this transformation takes place, practical and ethical questions of representation are not far away.

Of course, it would be a mistake to imagine that pedagogical issues were not considered prior to this transformation. For example, the publication of the Heidelberg catechism in 1563 as a pedagogical summary of the gospel, illustrates well pedagogical representation and reduction (Tröhler 2008). The catechism distils the essence of the gospel and elides theological controversies, attempting to meet the student where he or she is through forming questions that, it is supposed, exist within everyone. The authors of this representation of the gospel, and those who use it today, would recognise the need to consider how to best communicate something that is, in reality, complex. But the widespread systematic development of a pedagogical environment happened later (e.g. universal schooling in the nineteenth century), and can be related, albeit rather loosely, to the demand for stories, including folk and fairy tales, that can be retrofitted, as it were, to pedagogical ends. Some tales seem to lend themselves better than others for this kind of systematic pedagogical treatment, and so over time a canon forms of stories suited to moral edification. Although I call this a kind of reduction, whether this transformation is reductionistic is a complex question to which I briefly turn. 
I wish to make a distinction between pedagogical reduction and reductionism. The key difference here is that reductionism entails an idea that the representation is complete and sufficient in itself, while a pedagogical reduction is understood to be a pedagogical device used in a particular context, and therefore can only ever be a particular partial interpretation. For instance, it would be reductionist to interpret the catechism as a replacement for the gospel just as it would be reductionist to take a textbook entitled An Introduction to Quantum Mechanics to be the whole story of that subject. Related to this idea of the sufficiency of the representation we could speak of a risk of 'idolatry,' whereby the (constructed) representation is taken as complete and sufficient in itself, in contrast to an encounter or revelation. To illustrate this risk, let me refer to the Canadian Reformed Theological Seminary website which presents this catechism is following terms:

The Catechism summarizes the major teachings of Holy Scripture in one hundred and twentynine memorable questions and answers. Simple yet profound, as well as concise yet sufficient, the Catechism has been appreciated by young and old alike as one of the most clear, helpful and comforting guides into all the spiritual treasures of the holy gospel (An Ageless Summary of an Everlasting Comfort 2019).

The worry could be that by virtue of its sufficiency the catechism replaces the gospel. Although elsewhere the website points out that the catechism cannot replace the gospel, there is a danger that the representation is mistaken for that which it represents, a danger that educators must be vigilant to avoid. This example from the context of religion is more generally instructive since it concerns the systematic relation between the content of curricula, and the particular representation which takes account of pedagogical circumstances (particularly, the disposition and capacity of the student). My general point is that this kind of pedagogical reduction has its place as long as its educational purpose is kept in mind and that therefore its scope and limits are recognised. Indeed, this suggests that 'reductionism' is in the eye of the beholder in the sense that is it a matter of how representations and reductions are both employed by educators and received by students. So, we must recognise reduction as a process, one that entails a set of pedagogical relations, and that should avoid the reductionist attitude. While we might talk about the morals being reductions of the fables or fairy tales, we must always keep in mind that, in large part, reduction describes how the fable is used. In other words, fairy tales are not only objects 'out there' waiting to be used, but they involve telling: emphasis on the telling of the tale suggests that the meaning of the tale is contained also in how it is used and taken up.

There is a general distinction to be made between a justifiable pedagogical reduction (designed to aid understanding), and 'reductionism' (where the usage of a representation is thought to be complete requiring nothing further). The difference is that the reductionist flattens the hermeneutical relation to the world by failing to see the reduction as only that: one interpretation, whereas pedagogical reduction requires the interpreter (or the person providing the representation: e.g. the parent or teacher) to consider which story to choose as well as how the story should be told, such that the hermeneutical conditions of understanding are kept in mind. An interesting pedagogical issue is to what extent these hermeneutical conditions can be shared with the student, a point I will consider later when discussing practices of 'give and take' of pedagogical reductions. A moral reduction, as a pedagogical device and approach means recognising that any representation cannot be sufficient or complete. Although a moralistic reduction might withhold certain symbolic, allegorical and imaginal resonances of a story, this can be justified on pedagogical grounds. The educator would not (I would hope) deny the existence of these levels of resonance, but would determine how to represent these levels in the particular 
educational circumstances of the moment. Yet, it must be acknowledged that there are widespread anxieties about the use of pedagogical reductions to represent complex phenomena.

These anxieties are expressed in relation to the reductions of folk and fairy tales that are the focus on this article. For some interpreters, moralistic reductions obstruct the power of the text by eliding the complexities of the symbolic, allegorical and imaginal possibilities. More specifically, where canonical stories like the Tortoise and the Hare or Little Red Riding Hood become too familiar, readers become inured to the strangeness and ambiguity that is so much a part of these stories. Tyson Lewis argues against the reduction of fables to moral lessons because of a concern that reductions corrode the transformative power of them. Speaking of the "fundamental instability inherent in the fable as an ethical narration" (Lewis 2012, 329) Lewis reads these tales not as presenting simple morals in narrative form, but primarily about opening readers up to unsettling paradoxes: "To read a fable is not to extract a moral but instead to experience the unsettling of certainty and philosophical grounding in a moment of paradox" (Lewis 2012, 324). Lewis's point is important: fables often do have something of the nature of ambivalence and paradox built into them. Moreover, while interpreting the work of Thomas Keenan (1997), Lewis acknowledges the dual nature of the power of moral tales, first of the representation that simplifies, and second, the use or 'performance' of the fable:

all fables have a "conscious" task of erecting and solidifying borders between right and wrong, appearance and reality, and so on. Yet on the level of the performance of the fable (on the level of reading), these border controls are undermined with constant and unstoppable “unconscious" breaches in security (Lewis 2012, 328).

This conscious task seems broadly consistent with my notion of pedagogical reduction. Yet Lewis (and to some extent Keenan) appears to be committed to avoiding reduction in any forms. To illustrate the point, Lewis argues that in interpreting Aesop's fable of the wolf and the dog, Rousseau misinterprets the tears of the girl who, as we saw earlier, is upset that she must live as an enslaved dog:

If Rousseau refused to teach such fables to children because they would only contaminate the moral lessons of a pure natural education, and thus prevent the child from becoming socially responsible, then it is the very sheltering from the paradox of the fable that in the end prevents true responsibility in the face of uncertainty from ever being cultivated. (Lewis 2012, 328-9)

Up to a point I accept Lewis' argument here against Rousseau's reductionistic view of the moral lesson, but he seems to throw out the baby with the bath water. Surely we can embrace the complexity of the fable without also having to reject the notion of a pedagogical-moralistic reduction, in a more provisional sense, certainly in terms of how the story might be used. By suggesting that sheltering from paradox is anti-educational, Lewis seems to avoid consideration of the pedagogical circumstances in which it might be right to show the world to the young in such a sheltered way. Forms of sheltering are often important for educational experiences, whether in creating safe play areas for toddlers to explore, or textbooks that 'shelter' students from the contested debates of the otherwise 'paradigmatic' forms of truth that exist within a scientific community.

I acknowledge that there is a fundamental tension here between the view that education entails a representation of the world (by way of some form of reduction), and a view of education as a direct encounter with the world as such. The idea of education as an authentic experience of, or encounter with, the world is often traced to Dewey's notion of progressive education. Here the role of the teacher is not to represent complexity in simplified forms, but to bring about (or facilitate) an encounter with 
the world, which includes its illimitable complexity and paradox. Rousseau's conception of 'negative education' is, in certain respects similar, valorising the unmediated experience of the world that arises through autonomous discovery. These ideas sound a long way from sheltering; rather they appear to remove all barriers and shelters that seem derived from artifice. Yet for both Rousseau and Dewey, the notion of establishing certain conditions by manipulating the environment was also important. In Dewey we find an explicit reference to the reduction of experience in order to establish the best conditions for growth:

The first office of the social organ we call the school is to provide a simplified environment. It selects the features which are fairly fundamental and capable of being responded to by the young. Then it establishes a progressive order, using the factors first acquired as means of gaining insight into what is more complicated (Dewey 1916, 7).

In the context of fairy tales does this mean that teachers should avoid presenting children with a digest of moral messages couched in traditional, albeit sanitised, stories? Or should educators expose children to the complexity and ambivalence inherent to those stories (and to the world more generally)? One does not need to look far to find many well-known fairy tales that appear to be difficult to distil into simple moral messages. An excellent example is Hansel and Gretel which looks rather like a horrifying story of cannibalism and child abuse when read through the lens of a rationalist (like Richard Dawkins (Channel 4 News 2014)). Of course, such stories can be reduced: the basic moral of the story is usually interpreted as don't trust strangers and listen to your parents, but do we really need to have such horrifying narratives to convey these messages, especially where they are to be learnt by young children. On the other hand, bald moral directives are not "apt to delight and entertain a child" (Locke $2000,70)$. Of course, there are many positions to adopt along a spectrum from horror to boredom.

I accept that the ambiguity of meaning in these stories is not to a limitation, but is intrinsic to them, giving rise to reflection, and that, as Lewis puts it, "[a]s students of the fabulous, we are able to stand suspended between certainty and uncertainty, childhood and adulthood, freedom and authority" (Lewis 2012, 332). Simplistic interpretations risk avoiding sustained attention and reflection, while a story which has no simple moral has the capacity to hold us in a state of suspension which may itself be deeply educational and transformative. Lewis radicalises this view of fables, arguing that it gives the reader the "unbearable responsibility to think about the moral without recourse to any guarantee" (Lewis 2012, $324)$.

We see here an evocation of the poststructuralist insight that there is no end to the interpretation of texts, because every interpretation instantiates its own reduction. ${ }^{14}$ And yet one can ask when, pedagogically speaking, is the right time to bear responsibility for paradox without resolution, and when is it time to perform, or present, a provisional resolution? We can, in a sense, have our cake and eat it. We can stand for the ongoing hermeneutical task which settles for no single interpretation, while pedagogically speaking, deploying particular interpretations for particular educational effects at particular moments. Whether those effects are realised is another matter, but we can, and we do, at least make the attempt to select and simplify through moral stories. It is precisely through the provisionality of the reduction of the text that the selections and simplifications can be justified: educators will employ reductions in one moment and then determine when such a reduction must be exceeded. It is also essential to this notion of the provisionality of the pedagogical device that the educator at some point will draw attention to the limitations of a given reduction. This might mean that the educator leaves behind childish stories for more complex accounts, or it might mean that they

\footnotetext{
${ }^{14}$ In Gender Trouble, Judith Butler provides a crisp articulation of the 'basis' for poststructuralism as the rejection of "the claims of totality and universality and the presumption of binary structural oppositions that implicitly operate to quell the insistent ambiguity and openness of linguistic and cultural signification” (Butler 1990, 40).
} 
discuss the manner in which the stories are being reduced with the children, or some combination of the two approaches. The parallels with religious texts are, I believe, illuminating: the referential truth of the text may be illimitable, but the telling of the tale is not necessarily about understanding the truth in complete terms, but instantiating an understanding here and now. Since religious truth is often regarded as something that exceeds propositions, telling it always entails some kind of reduction, a discussion that is beyond my scope here (Lewin 2020).

\section{Conclusion}

I have examined the place of folk and fairy tales in the context of educational representation, developing a theory of moralistic reduction that acknowledges the processes of theoretical and practical necessity of representation without giving way to reductionism. I have suggested that the illimitable complexity of tales is certainly of value, but that such complexity is constantly augmented in relation to circumstances of representation that one finds oneself in. Much more could be said about the particular circumstances that shape the usage of pedagogical representations, and how those circumstances require us to employ the faculty of pedagogical tact in order to be sensitive to the effects of these pedagogical devices. ${ }^{15}$ Furthermore, the range of stories that are included in the rather loose notions of folk and fairy tales is so diverse that almost any general principle will be problematised by particular cases. However, the most fundamental ideas of pedagogical representation seem to be virtually ubiquitous requiring us to consider that, in fact, pedagogical representation and reduction is just another never-ending story.

\section{$\underline{\text { References }}$}

Aarne, A. (1961). The Types of the Folktale: A Classification and Bibliography, The Finnish Academy of Science and Letters, Helsinki.

Aesop (1912) Esop's Fables, translated by V. S. Vernon Jones, London: W. Heinemann.

Aldridge, D. (2014) ‘Rousseau's Pedagogical Hermeneutics and Some Implications for Moral

Education' in Lewin, Guilherme, and White (eds.) New Perspectives in the Philosophy of Education, London: Bloomsbury.

Aries, P. (1962) Centuries of Childhood. A Social History of Family Life, New York: Vintage Books.

Ashliman, D. (1997) 'Incest in Indo-European Folktales'

https://www.furorteutonicus.eu/germanic/ashliman/mirror/incest.html\#contents

Barthes, R. (1977) 'The Death of the Author' in Roland Barthes Image Music Text, Fontana Press, 142148.

Bennett, W., (1994) The Book of Virtues: A Treasury of Great Moral Stories, Simon \& Schuster Ltd.

\footnotetext{
${ }^{15}$ For discussion of pedagogical tact see, for instance, Van Manen (1992) and Lewis (2008).
} 
Bourke, R. (2008) 'First Graders and Fairy Tales: One Teacher's Action Research of Critical Literacy', The Reading Teacher, Vol. 62: 4.

Butler, J. (1990) Gender Trouble, London: Routledge.

Carter, A. (2008) The Fairy Tales of Charles Perrault, Penguin Modern Classics.

Channel 4 News (2014) 'Is Dawkins right about 'anti-scientific' fairy tales?'

https://www.channel4.com/news/richard-dawkins-fairy-tails-philip-pullman-scientific

Danilewitz, D. (1991) 'Once upon a time..... The meaning and importance of fairy tales', Early Child Development and Care, 75:1, 87-98, DOI: 10.1080/0300443910750104

Dewey, J. (1916) Democracy and Education, New York: Macmillan.

Ferguson, F. (1984) “Reading Morals: Locke and Rousseau on Education and Inequality," Representations 6: 77.

Geller, L. (1983). 'Children's Rhymes and Literacy Learning: Making Connections.' Language Arts, 60(2), 184-193.

Grenby, M. (2014) 'The origins of children's literature'

https://www.bl.uk/romantics-and-victorians/articles/the-origins-of-childrens-literature

Haase, D. (ed.) (2004) Fairy Tales and Feminism: New Approaches, Wayne State University Press.

Hand, M., (2017) A Theory of Moral Education, London: Routledge.

Heiner, H. "Fairy Tales Timeline" http://www.surlalunefairytales.com/introduction/timeline.html Lee, K., Talwar, V., McCarthy, A., Ross, I., Evans, A., \& Arruda, C. (2014). 'Can Classic Moral Stories Promote Honesty in Children?' Psychological Science, 25(8), 1630-1636. https://doi.org/10.1177/0956797614536401

Lewin, D. (2019) Toward a Theory of Pedagogical Reduction: Selection, Simplification and Generalisation in an Age of Critical Education, Educational Theory, 68: 495-512. doi: $10.1111 /$ edth. 12326

Lewin, D. (2020) 'Religion, Reductionism and Pedagogical Reduction' in Biesta and Hannam (eds.) Forthcoming.

Lewis, T. (2018) 'Can One Teach Tact?', Philosophy of Education Archive, Vol 2018, 1.

Lewis, T. (2012) 'Rousseau and the fable: Rethinking the fabulous nature of educational philosophy' Educational Theory, 62:3, 323-341.

Locke, J. (2000) Some Thoughts Concerning Education, ed John W. and Jean S. Yolton Oxford University Press.

Morley, E. (ed.) (1922) Blake, Coleridge, Wordsworth, Lamb, Etc. being Selections from the Remains of Henry Crabb Robinson, Manchester University Press.

Murray, C. (ed.) (2004) Encyclopedia of the Romantic Era, 1760-1850, London: Routledge. 
Newbery, J. (1787) A Little Pretty Pocket-Book Intended for the Instruction and Amusement of Little Master Tommy and Pretty Miss Polly, Worcester, Massachusetts: Isaiah Thomas.

Nikolajeva, M. (ed.) (1995). Aspects and Issues in the History of Children's Literature. Greenwood.

Qi, S. (2012) Western Literature in China and the Translation of a Nation, London: Palgrave.

Peters, R. (1966) Ethics and Education, Allen \& Unwin.

Rasmussen, (2019) 'The Gruffalo - from book to global brand', http://www.bookbrunch.co.uk/page/free-article/the-gruffalo--from-book-to-global-brand/

Repp, C., (2012) 'What's Wrong with Didacticism?' British Journal of Aesthetics 52: 3, pp. 271-286 DOI:10.1093/aesthj/ays023

Rousseau, J.-J. (1979) Emile, or on Education. Trans. William Payne, New York, NY: Appleton and Company [original publication 1762].

Rousseau, J.-J. (1992). Discourse on the Origin of Inequality. Indianapolis, Indiana: Hackett Publishing Co Shell, M., (1974) “The Lie of the Fox: Rousseau's Theory of Verbal, Monetary, and Political Representation," SubStance 4, no. 10: 116.

Sommers, (2002) 'How Moral Education is Finding its Way Back into America's Schools', in Damon, W. (ed.), Bringing in a New Era in Character Education. Stanford, CA: Hoover Institution Press, pp. $23-41$.

The Jubilee Centre for Character and Virtues (2019) https://www.jubileecentre.ac.uk/

The Nanjing Institute of Moral Education (2019) http://ime.njnu.edu.cn/

Thompson, S., (1955) Motif-Index of Folk-Literature: A Classification of Narrative Elements in Folk-Tales, Ballads, Myths, Fables, Mediaeval Romances, Exempla, Fabliaux, Jest-Books, and Local Legends, rev. and enl. edn, 6 vols, Copenhagen: Rosenkilde and Bagger.

Tröhler, D. (2008) 'The Knowledge of Science and the Knowledge of the Classroom: Using the Heidelberg Catechism (1563) to Examine Overlooked Connections,' in Emidio Campi, Simone De Angelis, Anja-Silvia Goeing, and Anthony Grafton (eds.) Scholarly Knowledge: Textbooks in Early Modern Europe, Geneva, Switzerland: Librarie Droz.

U.S. Department of Education (2005) Character Education... Our Shared Responsibility, https://www2.ed.gov/admins/lead/character/brochure.html

Van Manen, M., (1992) The Tact of Teaching: Meaning of Pedagogical Thoughtfulness, The Althouse Press

Winch, G. (2014) Literacy: Reading, Writing and Children's Literature, Fifth Edition. Oxford: Oxford University Press.

Wunderlich and Morrissey (2002) Pinocchio Goes Postmodern: Perils of a Puppet in the United States, London: Routledge.

Yolen, J. (2014) Favourite Folktales from Around the World New York: Random House Inc. 
Zipes, J. (2007) When Dreams Came True: Classical Fairy Tales and Their Tradition, London: Routledge. 